\title{
Responses to melatonin of 2 breeds of dairy ewes in early lactation under autumn photoperiod conditions
}

\section{A. Elhadi, $\odot$ A. A. K. Salama, $(1)$ X. Such, $\odot$ and G. Caja* $\odot$}

Group of Research in Ruminants (G2R), Department of Animal and Food Sciences, Universitat Autònoma de Barcelona, 08193 Bellaterra, Barcelona, Spain

\section{ABSTRACT}

A total of 72 dairy ewes of 2 breeds (MN, Manchega, $72.4 \pm 1.9 \mathrm{~kg}$ of body weight, $\mathrm{n}=36$; LC, Lacaune, $77.7 \pm 2.3 \mathrm{~kg}$ of body weight; $\mathrm{n}=36$ ) were used to evaluate the lactational effects of melatonin implants in early lactation and under the short-day photoperiod conditions of autumn (experiment was centered on the winter solstice). Ewes lambed in autumn and were penned indoors in 12 balanced groups of 6 ewes by breed, body weight, age, and number of lambs, and randomly assigned to a $2 \times 2 \times 3$ factorial design (treatment $\times$ breed $\times$ replicate). Ewes suckled their lambs for $28 \mathrm{~d}$. Treatments were (1) melatonin (MEL), which received 1 subcutaneous implant of melatonin (18 mg/ewe) in the ear base at $35 \pm 1 \mathrm{~d}$ ( 1 wk after lamb weaning), and (2) control, which did not receive any treatment. Ewes were fed ad libitum a total mixed ration (forage:concentrate, 60:40) and machine milked twice daily. Daily milk yield was automatically recorded from d 29 to 105 of lactation and sampled every 2 wk for composition. Jugular blood was sampled for plasma hormone analyses at 30,50, 80, 110, and 124 $\mathrm{d}$ of lactation. Body reserves were assessed every 2 wk. Feed intake was measured by pen during 3 separated periods after the start of the treatments (wk 2 to 3 , wk 6 to 7 , and wk 10 to 11). Feed intake, and milk yield and composition varied by breed, but no MEL effects were detected on dry matter intake, milk yield, milk composition, or fat and protein standardized milk in either breed. As a result of the unique composition of the implants and the variable body weights of the ewes, the MEL treatment dose (on average, $0.24 \mathrm{mg} / \mathrm{kg}$ of body weight) was $6.8 \%$ greater in the MN (lighter) than in the LC (heavier) ewes. Plasmatic melatonin markedly increased in the MEL-treated ewes (on average, 111\%), but despite the amount of MEL used, the MN responded greatly compared with the LC ewes (150 vs. 63\%,

Received September 10, 2021.

Accepted November 20, 2021.

*Corresponding author: gerardo.caja@uab.es respectively). No differences in basal plasmatic melatonin were detected between breeds $(6.4 \pm 1.1 \mathrm{pg} / \mathrm{mL}$, on average), indicating the greater responsiveness to the implants of the lighter MN ewes. Plasmatic prolactin tended to decrease in the MEL-treated ewes $(-35 \%$, on average), but the effect was significant only in the MN ewes $(-54 \%)$, in agreement with their greater response to MEL. No effects of MEL treatment were detected on plasmatic IGF-I in either breed. Moreover, body reserves did not vary by effect of MEL treatment or breed throughout the experiment. In conclusion, the use of exogenous melatonin as MEL implants, together with the endogenous melatonin naturally produced under short-day photoperiod conditions, had no effects on the early-lactation performances of dairy sheep, despite their breed and level of production.

Key words: dairy sheep, early lactation, melatonin, prolactin

\section{INTRODUCTION}

Sheep are seasonal breeder animals conditioned by photoperiodic signals that use melatonin (MEL) as a neuroendocrine transmitter for informing on the light:dark pattern (Bittman et al., 1983; Borjigin et al., 1999; Reiter et al., 2009). Melatonin is present in near all animal lineages and mainly secreted during the night into the cerebrospinal fluid (central) by the pineal gland and the visual system (retina, Harderian gland; Reiter, 1980, 1991). Extrapineal secretion (peripheral) and storage of MEL in endocrine (e.g., gut, liver, kidney, and so on) and nonendocrine (e.g., thymus, mast cells, leucocytes, and so on) cells has also been proved (Kvetnoy, 1999), but is unlikely to be dependent on light.

Light-dark treatments and administration of exogenous MEL to advance the breeding season and to improve the reproductive performances of small ruminants have been largely investigated. Administration of MEL has been shown to advance the beginning of the natural breeding season from the end of summer to spring by mimicking the stimulatory effect of autumnal 
short days in sheep and goats (Haresign et al., 1990; Williams et al., 1992; Zarazaga et al., 1998). Moreover, exogenous MEL does not suppress the endogenous nocturnal secretion of MEL, as reported by O'Callaghan et al. (1991) and Malpaux et al. (1997) in sheep.

Furthermore, MEL also controls the seasonal rhythm of prolactin (PRL) secretion by acting directly into the pituitary gland (Gómez-Brunet et al., 2008). The reduction of MEL secretion during long days is accompanied by an increase in PRL secretion in sheep (Lincoln and Clarke, 1994; Misztal et al., 1997). A reverse effect is observed during short days, where high MEL secretion inhibits PRL secretion and milk yield (Misztal et al., 2001; Molik et al., 2007). Dahl et al. (2000) concluded that milk production of dairy cows is negatively affected by a short-day photoperiod, resulting in high MEL, low PRL, and low IGF-I levels in blood.

The effects of MEL implants on lactational performances of dairy small ruminants is nowadays a controversial topic, with results conditioned by day-length conditions. Thus, on one hand, Abecia et al. (2005) reported that the use of MEL implants in Lacaune and Assaf dairy ewes during lactation in spring (long day) did not reduce milk yield. On the other hand, Molik et al. (2010) applied MEL implants in Polish Longwool ewes in early lactation under long-day (i.e., spring) and short-day (i.e., autumn) conditions, using untreated ewes under each photoperiod as control. The MELtreated ewes decreased PRL secretion, although the effect was only significant under long-day photoperiod. The lowest PRL values were observed in both MEL and control short-day ewes, and did not differ between them. Moreover, the authors reported greater growth hormone in the plasma of long-day ewes and short-day MEL-treated ewes, when compared with the other ewe groups.

In later research, Misztal et al. (2018) revisited the interaction of MEL and photoperiod in Polish Longwool sheep, with the aim of mitigating the negative effects of late lactation in ewes lambing under long-day photoperiod (June), when compared with those naturally lambing in short-day photoperiod (January). It should be stressed, to avoid misunderstandings with the terminology previously used, that in this case milking (started after a long suckling) was consequently performed mainly under short-day (autumn) and long-day (spring) photoperiods, respectively. Moreover, MEL was applied 6 wk before and 6 wk after lambing (2 doses with a 90 -d interval). So, according to Misztal et al. (2018), milk yield was greater in the long-day lactating ewes, in comparison with short-day $(-20 \%)$ and short-day treated with MEL $(-32 \%)$ lactating ewes. Interestingly, plasma MEL mean concentration at late pregnancy was inversely related to daylight duration and, on average, greater in the long-day than in the short-day MEL-treated lactating ewes. Little information is available with regard to effects of MEL on milk composition. Protein content of milk increased (15\%) in Polish Longwool ewes treated with MEL implants in mid lactation under spring conditions, as reported by Molik et al. (2012).

Based on the hypothesis that changes in MEL levels may affect milk production and composition, the aim of this study was to evaluate the lactational effects of subcutaneous MEL implants in 2 breeds of dairy sheep, basically differing in milk yield and milk composition (major differences) and in their body weight (minor difference), in early lactation and under short-day photoperiod conditions. With this aim, the experimental period was centered in the winter solstice (minimum day length), when the expected secretion of endogenous MEL should be maximum.

\section{MATERIALS AND METHODS}

The study was conducted in the experimental farm of the Servei de Granges i Camps Experimentals of the Universitat Autònoma de Barcelona in Bellaterra (Barcelona, Spain) located at N $41^{\circ} 30^{\prime} 20^{\prime \prime}$ and E $2^{\circ} 05^{\prime} 46^{\prime \prime}$ during a 14 -wk period, centered in the winter solstice (minimum day length, $9.25 \mathrm{~h}$ ). Animal care conditions and management practices agreed with the Spanish Royal Decree 53/2013 on the protection of animals used for experimental purposes, the codes of recommendations for the welfare of dairy sheep of the Ministry of Agriculture, Alimentation and Environment of Spain (MAPA, 2007), and the procedures stated by the Ethical Committee of Animal and Human Experimentation of the Universitat Autònoma de Barcelona.

\section{Ewe Management and Feeding}

A total of 72 ewes of 2 dairy breeds (Manchega, MN, $\mathrm{n}=36$; Lacaune, $\mathbf{L C}, \mathrm{n}=36)$ in early lactation (35 \pm 1 DIM) after the weaning of the lambs (28 DIM) were used. The ewes (MN vs. LC, respectively) differed in BW $(72.4 \pm 1.9$ vs. $77.7 \pm 2.3 \mathrm{~kg}$ of BW; $P=$ 0.045 ) but had similar BCS (on average, $2.99 \pm 0.12$ BCS units) and age (on average, $4.3 \pm 0.4 \mathrm{yr}$ ). All ewes wore plastic ear tags (Allflex Europe) and ceramic rumen mini-boluses (20 g; Datamars) for visual and electronic identification, respectively, that were used for automatic milk recording as described by Ait-Saidi et al. (2014).

Ewes were permanently sheltered on barley strawbedded pens and fed a TMR offered ad libitum. The main axis of the shelter was east-west oriented and had an open wall with slats on the south wall, allowing 
natural illumination and aeration. A supplementary program of artificial light for farm and milking management (morning, 0600 to $1000 \mathrm{~h}$; evening, 1800 to 2100 $\mathrm{h}$ ), providing $50 \mathrm{~lx}$ at the level of the ewes, was maintained constantly during the experiment. The TMR (forage:concentrate, 60:40\%; DM basis) consisted of alfalfa hay as forage and a farm-produced concentrate [ingredients: barley grain, 37.0\%; corn grain, $15.0 \%$; soybean hulls, $15.0 \%$; gluten feed, $10.0 \%$; soybean meal, $5.0 \%$; rapeseed 00 meal, $5.0 \%$; oat grain, $4.5 \%$; sunflower meal, $2.0 \%$; soybean oil, $2.0 \%$; cane molasses, $2.0 \%$; dicalcium phosphate, $1.0 \%$; calcium carbonate, $0.5 \%$; Vitafac Ovino-0.3 premix (DSM Nutritional Products), $0.5 \%$; and salt, $0.5 \%$; as fed], on a DM basis. Moreover, all ewes received $0.10 \mathrm{~kg}$ of corn whole grain at each milking, in the individual feeders of the milking parlor, to facilitate their entrance. Nutrient requirements were based on INRA (2010) and calculated by INRAtion v.4.07 (Educagri Éditions). Ewes had free access to water and commercial micromineral blocks (Multi-Block, Agrària Comarcal del Vallès).

Milking machine started on d 29 after abrupt weaning of the lambs. Milking procedures were like those described by Elhadi et al. (2019) and milking was conducted twice daily (0700 and $1700 \mathrm{~h})$ in a $2 \times 12$-stall parallel milking parlor (Amarre Azul I, DeLaval Equipos) with a central high-milk pipeline, silicone milking clusters (SG-TF100, DeLaval), and automatic milk-flow and milk recording devices (MM25SG, DeLaval).

\section{Experimental Treatments}

After the weaning of the lambs (28 d of age), the ewes were distributed in 12 balanced groups of 6 according to BW, BCS, age, milk yield, and milk composition. The experiment lasted $12 \mathrm{wk}$ and consisted of a 1-wk adaptation period (28 to 35 DIM) and 11-wk posttreatment period (36 to 112 DIM). The experimental design consisted of a factorial with 2 treatments $\times 2$ breeds $\times 3$ replicates, to which the ewe groups were randomly allocated. Treatments were MEL $(\mathrm{MN}, \mathrm{n}=$ 18; and $\mathrm{LC}, \mathrm{n}=18$ ) consisting of a single MEL implant (18 mg/ewe, Melovine, Ceva Animal Health), applied subcutaneously in the base of the ear at $35 \pm 1$ DIM; and control (MN, $\mathrm{n}=18$; and $\mathrm{LC}, \mathrm{n}=18$ ) that did not receive any treatment. At the treatment day, all the ewes were restrained in the head locker of the feed bunk after the p.m. milking and the MEL ewes were implanted with a single implant in the left ear.

\section{Measurements, Sampling, and Analyses}

Milk Yield. Milk yield of individual ewes was recorded at each milking during the whole experiment (85 d), using the milk-flow and milk recording automatic units of the milking parlor. Data were uploaded using the AlPro software 7.2 (DeLaval) and daily reviewed and uploaded into a spreadsheet to avoid incorrect values.

Milk Composition. Representative milk samples of each ewe were taken pre- $(\mathrm{d}-3)$ and posttreatment (d $15,30,45$, and 75 ), corresponding to $32,50,65,80$, and 110 DIM, for compositional analysis using proportional milk samplers (MM25SG, DeLaval). Milk samples (50 $\mathrm{mL}$ ) were composited according to the daily milking intervals (a.m.:p.m., 60:40), preserved with an antimicrobial tablet (Bronopol, Broad Spectrum Micro-tabs II, D\&F Control Systems) and stored at $4^{\circ} \mathrm{C}$ until analysis. Milk samples were analyzed in the Dairy Herd Improvement Laboratory of Catalonia (ALLIC) for fat, total protein, lactose, and urea (Milkoscan FT2, Foss) and SCC (Fossomatic 5000, Foss).

Feed Intake. Feed intake of each group was assessed daily at the start (wk 2 and 3), mid (wk 6 and 7), and final (wk 10 and 11) periods posttreatment by measuring the amount of feed offered and refused in each pen of 6 ewes. No refusals of concentrate were observed in the milking parlor. The TMR offered in the pens and their refusals were sampled daily and composited weekly for pre- and posttreatment periods feed analysis.

Feed Analyses. The DM content was determined by gravimetry, desiccating the sample in a forced-air stove $\left(103^{\circ} \mathrm{C}\right.$ for $\left.24 \mathrm{~h}\right)$ and $\mathrm{OM}$ content was also measured gravimetrically by ashing the samples in a muffle furnace $\left(550^{\circ} \mathrm{C}\right.$ for $\left.4 \mathrm{~h}\right)$ according to AOAC (1990). Cellulose was analyzed as crude fiber according to AOAC (1990), and NDF and ADF were determined, on an ash-free basis, by adding amylase and sodium sulfite solutions according to Van Soest et al. (1991) and using an Ankom200 Fiber Analyzer incubator (Ankom Technology). Total $\mathrm{N}$ was determined by combustion according to the Dumas method using a Leco analyzer (Leco Corporation), and $\mathrm{CP}$ was calculated as $\mathrm{N} \times$ 6.25 .

Blood Measures. Blood samples were taken from the jugular vein using 10-mL Vacutainer tubes with lithium heparin 170 IU (BD, Belliver Industrial Estate) at $0800 \mathrm{~h}$, after the morning milking and before feeding, at $\mathrm{d}-5$ pre-treatment and d 15, 45, 75, and 89 posttreatment (corresponding to $30,50,80,110$, and 124 DIM). This sampling time was chosen to assess the basal level of MEL with or without the implants. Plasma was obtained by whole blood centrifugation for $15 \mathrm{~min}$ at $2,000 \times \mathrm{g}$ and $4^{\circ} \mathrm{C}$, transferred to $0.5-\mathrm{mL}$ Eppendorf tubes, and stored at $-20^{\circ} \mathrm{C}$ for analyses. Hormone analyses in plasma were performed according to the ELISA sandwich type method by using MEL (LDN), PRL (DIASource Immunoassays), and IGF-I (Mediagnost) kits. The stopped ELISA plates 
were read in an automatic reader (iEMS Reader MF V.2.9-0, Labsystems España) at $450 \mathrm{~nm}$. Sensitivity and intra- and interassay coefficients of variation were MEL $(1.0 \pm 0.2 \mathrm{pg} / \mathrm{mL}, 8.5 \%$, and $11.1 \%)$, PRL $(0.35$ $\pm 0.07 \mathrm{ng} / \mathrm{mL}, 4.5 \%$, and $5.9 \%)$, and IGF-I $(0.09 \pm$ $0.02 \mathrm{ng} / \mathrm{mL}, 8.0 \%$, and $9.9 \%$ ), respectively.

Body Reserves. The BW and BCS of all ewes were evaluated $1 \mathrm{wk}$ before the start of experiment, to allocate the ewes in balanced groups during the adaptation period, and at d 15, 30, 45, and 75 posttreatment (corresponding to $28,50,65$, and $80 \mathrm{DIM}$ ). Weighing was performed using an electronic scale (Tru-Test A6500), and BCS was assessed ( 0 to 5 points; accuracy, \pm 0.25 points) according to Russel et al. (1969).

\section{Statistical Analyses}

Data were analyzed by the MIXED procedure for repeated measurements of SAS v.9.4 (SAS Institute Inc.). The statistical mixed model included the breed (MN and LC), the melatonin treatment (MEL and control), the sampling time, and the breed $\times$ treatment and the treatment $\times$ sampling interactions as fixed effects, as well as the random effects of the experimental unit (ewe, for individual measurements, or pen for intake), and the residual error. No significant interactions $(P>$ $0.20)$ were removed from the model. Values of the variables were computed for their respective treatment and sampling dates, the means expressed as least squares means and separated by pairwise comparison using the PDIFF test of SAS. Pearson correlation coefficients (r) were calculated using the CORR procedure of SAS. Significance was declared at $P<0.05$ and a tendency was considered when $P<0.10$.

\section{RESULTS AND DISCUSSION}

Although the dose of MEL (18 mg/ewe) was the same for the MN and LC ewes, because of the difference in $\mathrm{BW}$ between breeds (i.e., the $\mathrm{LC}$ ewes were $5.3 \mathrm{~kg}$ heavier than the MN), the mean MEL treatment dose $(0.240 \mathrm{mg} / \mathrm{kg}$ of BW $)$ was $6.8 \%$ lower in the LC $(0.232$ $\mathrm{mg} / \mathrm{kg}$ of BW) compared with the $\mathrm{MN}(0.249 \mathrm{mg} / \mathrm{kg}$ of BW) ewes. This source of variation has not been considered in previous studies and should be considered in the analysis of our results and for further research. The main results of MEL treatment on the lactational performances of the studied dairy ewes in early lactation are summarized in Table 1.

Table 1. Effects of melatonin implants (18 mg/ewe) under short-day conditions of 2 breeds of dairy ewes in early lactation (LSM \pm SEM)

\begin{tabular}{|c|c|c|c|c|c|c|c|c|c|}
\hline \multirow[b]{2}{*}{ Item } & \multicolumn{2}{|c|}{ Manchega } & \multicolumn{2}{|c|}{ Lacaune } & \multirow[b]{2}{*}{ Mean } & \multirow[b]{2}{*}{ SEM } & \multicolumn{3}{|c|}{ Effect ( $P$-value $)$} \\
\hline & $\mathrm{CO}^{1}$ & $\mathrm{MEL}^{1}$ & $\mathrm{CO}$ & MEL & & & Melatonin & Breed & Interaction $^{2}$ \\
\hline Intake, $\mathrm{kg}$ of $\mathrm{DM} / \mathrm{d}$ & 2.26 & 2.19 & 3.37 & 3.29 & 2.78 & 0.07 & 0.32 & 0.001 & 0.96 \\
\hline \multicolumn{10}{|l|}{ Milk yield } \\
\hline Yield, kg/d & 1.43 & 1.32 & 2.54 & 2.51 & 1.95 & 0.15 & 0.67 & 0.001 & 0.80 \\
\hline $\mathrm{ECM},{ }^{3} \mathrm{~kg} / \mathrm{d}$ & 1.37 & 1.28 & 2.13 & 2.16 & 1.73 & 0.14 & 0.68 & 0.001 & 0.90 \\
\hline Fat, $\mathrm{g} / \mathrm{d}$ & 99 & 93 & 138 & 143 & 118 & 9 & 0.74 & 0.001 & 0.69 \\
\hline Protein, g/d & 81 & 76 & 135 & 136 & 107 & 8 & 0.91 & 0.001 & 0.67 \\
\hline Lactose, $\mathrm{g} / \mathrm{d}$ & 70 & 64 & 121 & 120 & 93 & 8 & 0.84 & 0.001 & 0.77 \\
\hline $\mathrm{TS}, \mathrm{g} / \mathrm{d}$ & 264 & 246 & 419 & 423 & 338 & 26 & 0.75 & 0.001 & 0.92 \\
\hline \multicolumn{10}{|l|}{ Milk content } \\
\hline Fat, $\%$ & 6.92 & 7.06 & 5.44 & 5.71 & 6.28 & 0.18 & 0.27 & 0.001 & 0.72 \\
\hline Protein, \% & 5.69 & 5.77 & 5.34 & 5.43 & 5.56 & 0.10 & 0.42 & 0.002 & 0.95 \\
\hline Lactose, \% & 4.87 & 4.83 & 4.76 & 4.77 & 4.81 & 0.08 & 0.84 & 0.30 & 0.75 \\
\hline $\mathrm{TS}, \%$ & 18.5 & 18.6 & 16.5 & 16.9 & 17.6 & 0.2 & 0.27 & 0.001 & 0.68 \\
\hline Urea, g/L & 64.9 & 66.5 & 56.4 & 58.3 & 61.5 & 1.5 & 0.26 & 0.001 & 0.94 \\
\hline $\mathrm{SCC}, \log _{10} / \mathrm{mL}$ & $5.82^{\mathrm{x}}$ & $5.30^{y}$ & 5.55 & 5.46 & 5.53 & 0.15 & 0.063 & 0.72 & 0.19 \\
\hline \multicolumn{10}{|l|}{ Plasma hormone } \\
\hline Melatonin, pg/mL & $6.88^{\mathrm{b}}$ & $17.18^{\mathrm{a}}$ & $5.75^{\mathrm{b}}$ & $9.40^{\mathrm{a}}$ & 9.80 & 1.05 & 0.001 & 0.001 & 0.002 \\
\hline Prolactin, ng/mL & $19.8^{\mathrm{a}}$ & $9.1^{\mathrm{b}}$ & 13.2 & 11.1 & 13.3 & 3.4 & 0.050 & 0.49 & 0.19 \\
\hline IGF-I, ng/mL & 258 & 283 & 272 & 294 & 276 & 27 & 0.41 & 0.66 & 0.97 \\
\hline \multicolumn{10}{|l|}{ Body reserves } \\
\hline $\mathrm{BW}$ variation, $\mathrm{kg} / 30 \mathrm{~d}$ & 1.17 & 2.09 & 2.85 & 2.29 & 2.10 & 0.51 & 0.73 & 0.076 & 0.16 \\
\hline $\mathrm{ADG}, \mathrm{g} / \mathrm{d}$ & 38.9 & 69.8 & 94.9 & 76.5 & 70.0 & 16.9 & 0.72 & 0.077 & 0.16 \\
\hline BCS variation in $30 \mathrm{~d}$ & 0.22 & 0.13 & 0.08 & 0.10 & 0.13 & 0.06 & 0.52 & 0.18 & 0.33 \\
\hline
\end{tabular}

\footnotetext{
${ }^{\mathrm{a}, \mathrm{b}}$ Within a row and breed, values with a different superscript differed $(P<0.05)$.

${ }^{\mathrm{x}, \mathrm{y}}$ Within a row and breed, values with a different superscript tended to differ $(P<0.10)$.

${ }^{1} \mathrm{CO}=$ control; $\mathrm{MEL}=$ melatonin.

${ }^{2}$ Melatonin $\times$ breed.

${ }^{3} \mathrm{ECM}=$ milk yield $\times[0.071 \times($ fat, $\%)+0.043 \times($ total protein, $\%)+0.2224]$, acco $]$ rding to INRA $(2010)$.
} 


\section{Feed Intake}

Voluntary feed intake values of the dairy ewes are shown in Table 1. No effects of the MEL implants on feed intake were detected in either breed (on average, $2.78 \pm 0.07 \mathrm{~kg}$ of $\mathrm{DM} / \mathrm{d} ; P=0.32$ ) during the $3 \mathrm{ex}-$ perimental periods studied [start (wk 2 and 3), mid (wk 6 and 7), and final (wk 10 and 11)] after MEL implantation.

Although, to our knowledge, the effect of MEL implants on feed intake in sheep is not well documented, MEL alters leptin signaling in sheep with a greater appetite-depressing effect of leptin being observed in short natural day lengths (Adam and Mercer, 2004). Song and Chen (2009) reporter greater plasmatic levels of leptin and lower feed intake in water-supplemented MEL mice. Bocquier et al. (1997) observed that DMI of lactating Sarda dairy ewes under the short-day photoperiod treatment was lower $(-16 \%)$ than ewes under long days. Lacasse et al. (2014) reported a $4 \%$ decrease of DMI in Holstein cows fed MEL and under long-day photoperiod, when compared with those under shortday photoperiod conditions. The effect of photoperiod length on feed intake was not significant in lactating Saanen dairy goats under short- and long-day photoperiod conditions (Mabjeesh et al., 2007). Consequently, according to these data, a slight decrease or no effect in DMI should be expected when dairy ewes are treated with MEL implants during lactation.

The effect of the breed on DMI was important in our results, and on average, MN ewes ate $33 \%$ less DM than did LC ewes $(P<0.001 ;$ Table 1$)$. This result agrees with the greater milk yield of the LC ewes $(P$ $<0.001$ ), as later discussed, and with the results of previous studies comparing both breeds in the same stage of lactation (Molina et al., 2001; Flores et al., 2008; Elhadi et al., 2019). No MEL $\times$ breed interaction was detected on the feed intake of our ewes $(P=0.96$; Table 1).

\section{Milk Yield}

No differences by effect of MEL treatment were detected on milk yield $(P=0.67)$ and ECM $(P=0.68)$ in both breeds (Figure 1). No MEL $\times$ breed interaction was detected on milk yield or milk components yield of our ewes $(P=0.67$ to 0.92$)$ as shown in Table 1 and Figure 1. On average, and for the same stage of lactation, LC ewes yielded $83 \%$ more milk than MN ewes did (LC vs. MN, $2.53 \pm 0.15$ vs. $1.38 \pm 0.15 \mathrm{~kg} / \mathrm{d}$; $P<0.001)$ throughout the experiment. The lactation persistency linear coefficients in early lactation (35 to 95 DIM) were similar for the MN and LC ewes $(-11$ and $-14 \mathrm{~g} / \mathrm{d}$, respectively; $P=0.83$ ).
Our results agreed with those of Abecia et al. (2005) who reported no effects on milk yield throughout the milking period of Lacaune and Assaf dairy ewes lambed in autumn and winter, respectively, and treated with MEL implants in spring (long-day) conditions. On the contrary, Molik et al. (2013) in Polish Longwool ewes milked after suckling in spring (long-day) conditions, reported that MEL-treated and artificial short-day (200 lx light during 8-h) treated ewes yielded less milk ( $-16 \%$ and $-38 \%$, respectively), than control ewes under natural long-day photoperiod. Nevertheless, in this study, MEL implants were applied twice during lactation (weaning, d 57; late lactation, d 147), although the authors did not report the plasmatic MEL values. Bocquier et al. (1997) also reported that Sarda dairy ewes produced $-25 \%$ milk under short-day photoperiod (light:dark, 8:16) than those under long-day (16:8) conditions during lactation.

Misztal et al. (2018) reported that milk yield of Polish Longwool sheep ewes, implanted twice with MEL (in late pregnancy in spring and in early lactation in autumn), or left as control under the same photoperiod conditions, was greater in the long-day lactating ewes, when compared with the control in short-day $(-20 \%)$ and the MEL treated in short-day $(-32 \%)$ conditions. Despite the species differences, the use of MEL during late pregnancy (2 implants of $18 \mathrm{mg} /$ goat) was also studied by Avilés et al. (2019) in Creole goats dried off during the summer solstice that kidded in late August and were suckled and milked during autumn (short day). The MEL treatment, removed surgically at kidding, stimulated the subsequent lactational performances and increased milk yield more than 20\% during suckling (as well as kid growth) and milking, but milk composition was not affected. This increase in milk yield agreed with those reported in Holstein cows (Auchtung et al., 2005) and Saanen goats (Mabjeesh et al., 2013) exposed to artificial short days (light:dark, 8:16 h) during the dry period, which produced more milk in the subsequent lactation under natural long-day photoperiod. It should be stressed that in the Mabjeesh et al. (2013) experiment the goats were under hot weather conditions in late pregnancy, which is known to dramatically increase PRL levels, as later discussed. Nevertheless, Dahl et al. (2000) and Lacasse et al. (2014) reported that feeding MEL during late pregnancy had no effects on the subsequent milk yield of Holstein dairy cows, but the result may have been conditioned to the MEL source. Thus, Auldist et al. (2007) evaluated the effects of repeated MEL implants during $12 \mathrm{wk}(6 \times 18 \mathrm{mg} / \mathrm{cow})$ in twin New Zealand Friesian dairy cows calved in spring. The use of MEL implants decreased milk yield $(-23 \%)$ and increased milk contents, as in late lactation. Auldist et al. (2007) concluded that some of the milk changes 
observed in New Zealand throughout the summer may be a consequence of the MEL increase associated with the decreasing day length.

\section{Milk Composition}

No changes on milk components by effect of MEL treatment, under short-day conditions (winter solstice), were detected in our ewes throughout the experiment, as well as on the daily yield of different milk components $(P=0.25$ to 0.99 ; Table 1$)$. On the other hand, marked differences in milk fat and milk protein contents were observed between MN and LC breeds (Figure 2), but not in their lactose content $(P=0.84)$, as previously reported for the 2 breeds under similar conditions (Flores et al., 2008; Elhadi et al., 2019). Only SCC tended to decrease by effect of the MEL treatment in the case of MN ewes $(P=0.063)$.

On the contrary, Molik et al. (2012) reported that the administration of MEL increased the protein content $(15 \%)$ of the milk of Polish Longwool ewes under long-day photoperiod. Moreover, Bocquier et al. (1997), in Sarda, and Molik et al. (2012), in Polish Longwool ewes, also reported the positive effects of short days versus long days on milk protein content (4\% and 15\%, respectively). Nevertheless, implanting MEL to Creole goats during late pregnancy (Avilés et al., 2019) did not change milk composition and the use of short-day photoperiod during late pregnancy in Saanen dairy goats did not change their milk composition (Mabjeesh et al., 2007). With regard to dairy cows treated with MEL implants during summer in New Zealand, Auldist et al. (2007) reported increases in milk fat and protein contents (14\% and $7 \%$, respectively), whereas lactose content decreased $(-7 \%)$, but no effects were detected by Lacasse et al. (2014) when the milk of short-day, long-day, and MEL-fed lactating Holstein cows under long-day photoperiod was compared.

\section{Plasmatic Hormones}

Hormonal values in the plasma of our ewes according to treatments and breed are summarized in Table 1 and changes of basal MEL through the experiment are shown in Figure 3. Plasmatic levels of MEL in sheep are highly variable among individuals (i.e., 0 to 300 $\mathrm{pg} / \mathrm{mL}$ ), but the nocturnal MEL concentration is high $(>100 \mathrm{pg} / \mathrm{mL})$ and characteristic of each individual, which is indicative of a genetic control (Chemineau et al., 1996; Zarazaga et al., 1998). On the contrary, MEL levels are low (i.e., 0 to $10 \mathrm{pg} / \mathrm{mL}$ ) and stable after the dawn (O'Callaghan et al., 1991). Because the pineal

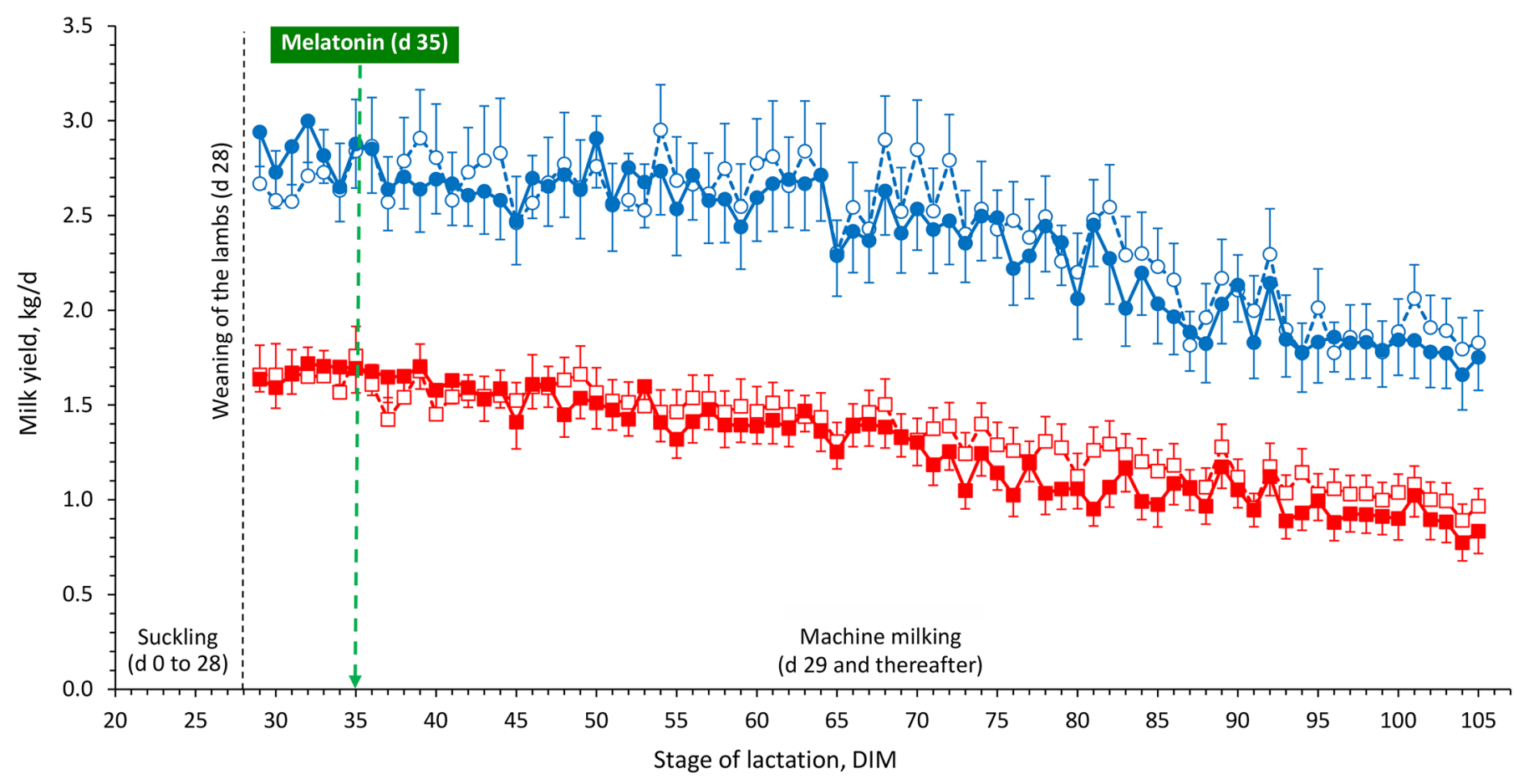

Figure 1. Effects of a single s.c. melatonin implant (MEL; $18 \mathrm{mg} /$ ewe, d 35) on milk yield of Manchega ( $\square$, MN-control; $\mathbf{\square}$, MN-MEL) and Lacaune $(\mathrm{O}$, LC-control; $\bullet$, LC-MEL) dairy ewes in early lactation (35 DIM) under autumn photoperiod conditions. Treatments: melatonin (solid lines and closed symbols, $\square$ and $\bullet$ ) or control (broken lines and open symbols, $\square$ and $\bigcirc$ ). Values are LSM with the SEM indicated by vertical bars. 
MEL (central) is mainly secreted during the night and its concentration falls after dawn, values obtained from blood samples collected from the control ewes after the a.m. milking represented, according to Kvetnoy (1999), the basal endogenous extrapineal MEL secretion (peripheral) during the short-day photoperiod conditions of our experiment. On the other hand, the values of the MEL-treated ewes after d 35, when the slow-release

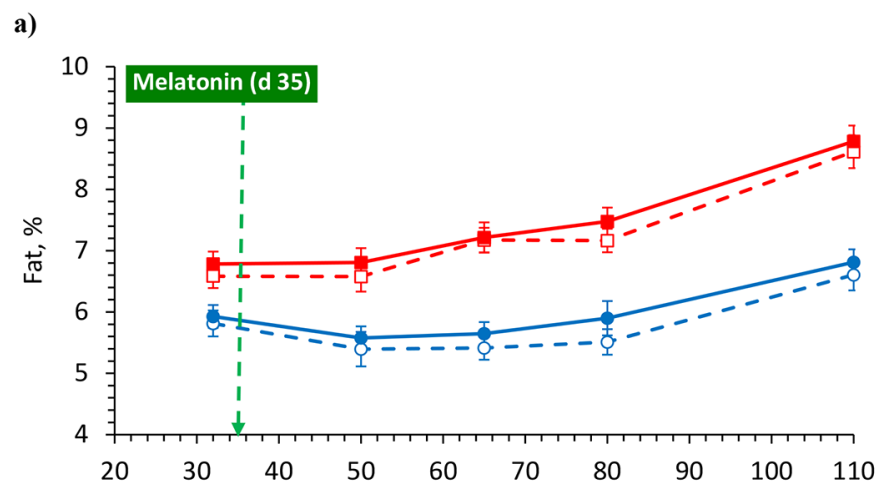

b)

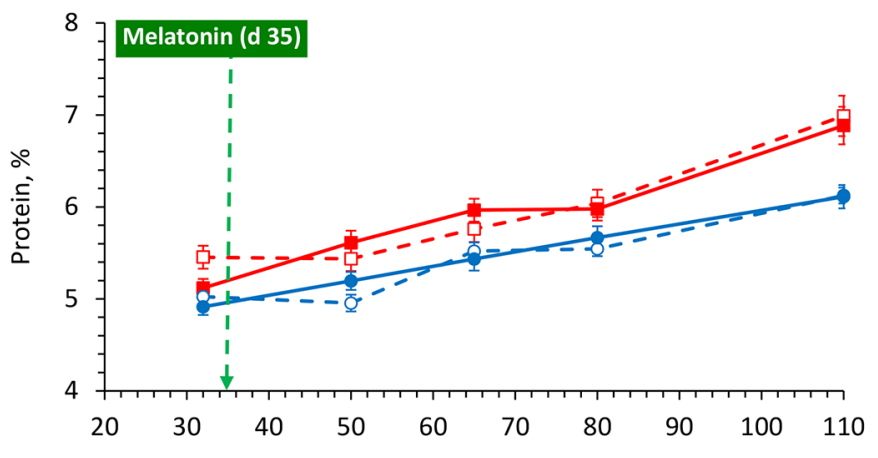

c)

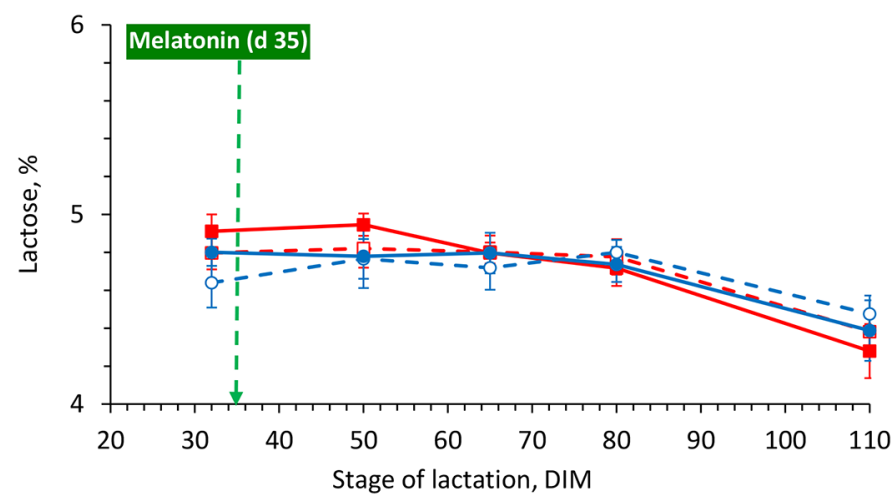

Figure 2. Effects of a single s.c. melatonin implant (MEL; 18 mg/ewe, d 35) on milk composition (a, fat; b, protein; c, lactose) of Manchega ( $\square$, MN-control; $\mathbf{\square}$, MN-MEL) and Lacaune (O, LC-control; -, LC-MEL) dairy ewes in early lactation (35 DIM) under autumn photoperiod conditions. Treatments: melatonin (solid lines and closed symbols, - and o) or control (broken lines and open symbols, $\square$ and O). Values are LSM of both breeds averaged, with the SEM indicated by vertical bars. implants were applied, represented the total MEL concentration in blood (endogenous-peripheral secretion plus exogenous).

As shown in Figure 3, no changes in the basal MEL values were observed in the control ewes throughout the experiment $(6.4 \pm 1.2 \mathrm{pg} / \mathrm{mL}$, on average; Table 1$)$, although MN showed numerically greater basal MEL values than $\mathrm{LC}$ ewes. After the insertion of implants (18 mg/ewe), MEL values in plasma increased markedly in the treated ewes, but this increase was greater in MN than in LC ewes (150 vs. $63 \%$, respectively; $P$ $<0.001$ ). Such differences were not explained by the practical MEL doses reported in our ewes according to breed BW (MN, $0.249 \mathrm{mg} / \mathrm{kg}$ of BW; LC, 0.232 $\mathrm{mg} / \mathrm{kg}$ of $\mathrm{BW}$ ) and should be explored by further research. Plasmatic MEL values in the treated ewes reached a plateau of at least $60 \mathrm{~d}$ (d 50 to 110, Figure 3 ) and decreased to basal values thereafter (d 125). The difference between breeds was unexpected and we hypothesized that it may be a consequence of differences in the metabolization of exogenous MEL, which could be associated with the greater metabolic activity of the higher yielding LC ewes, as well as with the greater BW and BCS (Table 1) observed in MN than in $\mathrm{LC}$ ewes. Melatonin is recognized by its functional synergism with insulin, decreasing glycemia and insulin resistance (Cipolla-Neto et al., 2014).

After the discovery of association of MEL receptor gene MTNR1A (MT1) polymorphisms with sheep fertility (Notter and Chemineau, 2001; Notter et al., 2003), Mura et al. (2010) reported stronger effects of exogenous MEL on the reproductive activity of Sarda dairy ewes homozygous to the MT1 favorable allele $(+/+)$. This would also explain the link between genotype and photoperiod, as the - / - ewes need higher and long-lasting levels of MEL in blood to be stimulated for reproduction. It should be stressed that, in our MN and LC experimental flock, adult ewe and hogget fertility during spring was repeatedly greater in LC than in MN sheep (data not shown).

Consequently, the use of a unique dose of MEL recommended in practice (a single implant of $18 \mathrm{mg}$ / ewe) may be questioned and further study is needed to determine if it is optimal for heavier and high-yielding dairy sheep breeds (e.g., Assaf and East Friesian ewes).

Misztal et al. (2018) reported dramatic increases of nocturnal blood MEL in Polish Longwool ewes when compared short-day photoperiod $(400 \%)$ or MEL implanted under long-day conditions (425\%), with longday photoperiod as control. The increases were greater than in our results as a consequence of sampling time, which was after the sunset in Misztal et al. (2018) and included the nocturnal MEL secretion, whereas it was after the dawn (i.e., only basal) in our experiment. 
In agreement with the greater plasmatic MEL level of the MN-treated ewes, plasma concentration of PRL decreased $(-54 \%)$ when compared with MN-control ewes (Table 1). No effects between treatments were detected in the LC ewes. Molik et al. (2013) and Misztal et al. (2018) also reported decreases in plasma PRL concentration of the MEL-treated Polish Longwool ewes $(-22 \%)$. According to Misztal et al. (2018), plasma PRL in the long-day ewes increased from late pregnancy (winter) to weaning (spring), whereas in the short-day and the short-day MEL-treated ewes the direction of change was the opposite, with the lowest PRL concentration occurring at weaning (August).

The decreasing effect of exogenous MEL on PRL secretion was also observed during increasing photoperiod conditions, despite the strong stimulation induced by the suckling of the lambs (Molik et al., 2010). A marked PRL decrease $(-46 \%)$ was also observed in lactating Saanen dairy goats under a short-day photoperiod (Mabjeesh et al., 2007) and in MEL-treated New Zealand Friesian dairy cows (Auldist et al., 2007), compared with the control ones. In the Mabjeesh et al. (2013) experiment, all of the goats were submitted to heat-stress in late pregnancy, which is known to dramatically increase PRL levels (Hooley et al., 1979). The positive effects of short days during pregnancy on milk yield were attributed to the inhibitory effects of MEL on PRL secretion, which stimulated the involution of the mammary gland and increased the expression of PRL-receptors in different tissues (Auchtung et al., 2005), such as in the mammary gland and liver. Thus, the higher the plasma MEL concentration, the lower the PRL concentration in blood, and vice versa, such as observed in our MN and LC ewes.

No changes in plasma IGF-I values by effect of MEL treatment were detected in our ewes of either breed $(P=0.66$; Table 1). Nevertheless, Mabjeesh et al. (2007) reported a $68 \%$ decrease in plasma IGF-I values of short-day photoperiod lactating Saanen dairy goats and Auldist et al. (2007) in MEL-treated cows reported a decrease in PRL plasmatic concentrations, but values of IGF-1 did not change.

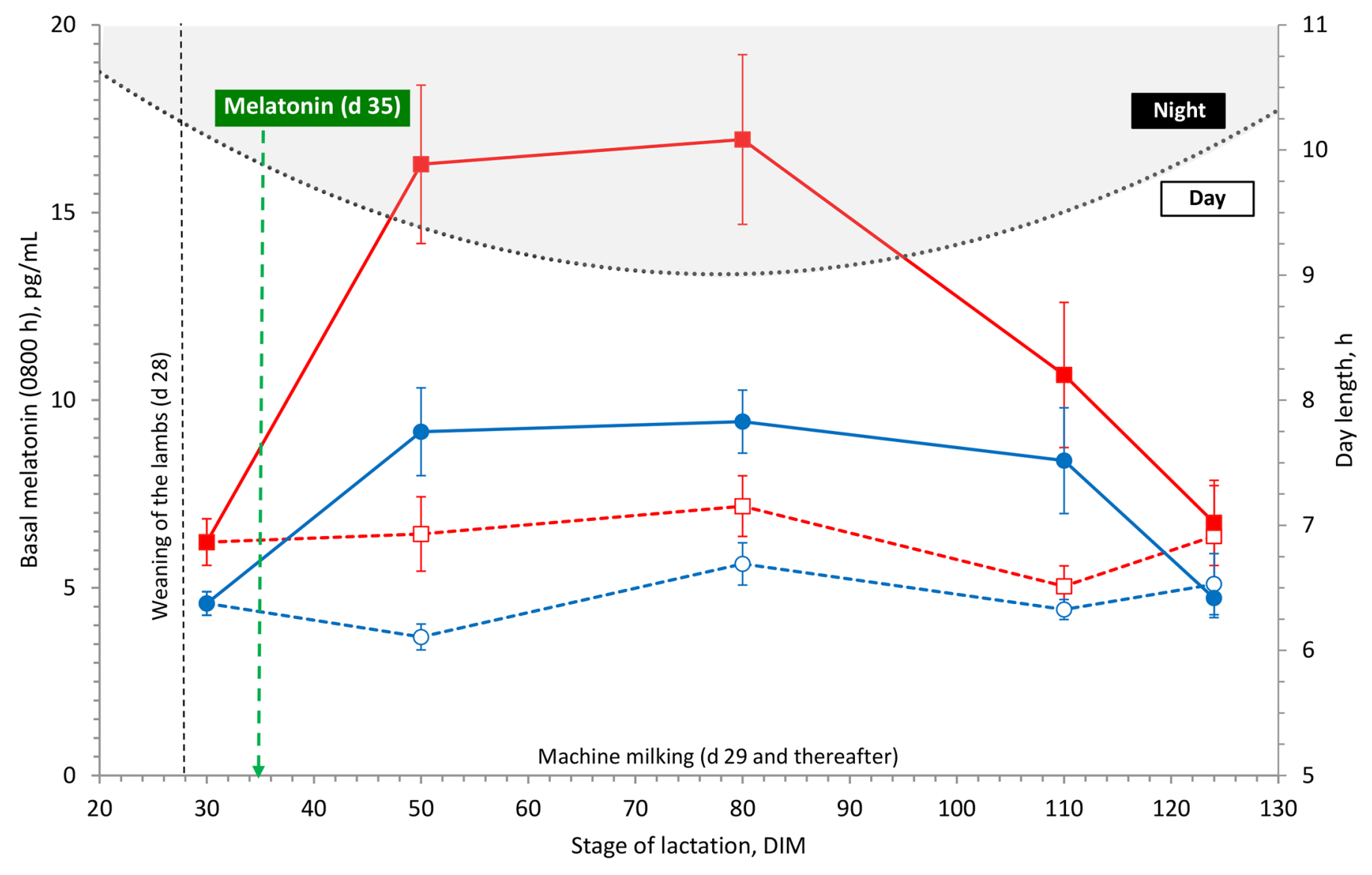

Figure 3. Effects of a single s.c. melatonin implant (MEL; $18 \mathrm{mg}$ /ewe, d 35) on plasma melatonin of Manchega ( $\square$, MN-control; $\mathbf{\square}$, MNMEL) and Lacaune ( $\mathrm{O}, \mathrm{LC}-\mathrm{control}$; - LC-MEL) dairy ewes in early lactation under autumn photoperiod conditions. Treatments: melatonin (solid lines and closed symbols, $\square$ and $\bullet$ ) or control (broken lines and open symbols, $\square$ and $\bigcirc$ ). Gray area and dotted line show the daylight duration. Values are LSM with the SEM indicated by vertical bars. 


\section{Body Reserves}

The BW and BCS of our ewes are shown in Table 1. Despite the previously mentioned effects of MEL on leptin signaling, MEL treatment had no effects on BW or BCS $(P=0.30$ to 0.79$)$ of the ewes of either breed. On average, BW and BCS were $77.9 \pm 1.1 \mathrm{~kg}$ and 3.02 \pm 0.05 units for early lactation under short-day photoperiod conditions. Bocquier et al. (1997) also found no effect of photoperiod length on body reserves of lactating Sarda dairy ewes. No differences were found within and between the short-day, long-day, and the MEL with long-day treatment in lactating Polish Longwool ewes (Misztal et al., 2018).

\section{CONCLUSIONS}

The use of exogenous MEL, together with the effect of the endogenous MEL under decreasing photoperiod conditions, had no significant effects on milk yield and composition of medium- and high-yielding dairy ewes in early lactation. Plasmatic PRL tended to decrease in the MEL-treated ewes, although the effect was only significant in the MN ewes. On the other hand, marked differences in MEL plasmatic values were observed in the response to the same dose of MEL implants (18 $\mathrm{mg}$ /ewe) between breeds, the effect of the dose being greater in the MN ewes, which needs further research.

\section{ACKNOWLEDGMENTS}

This study was partially funded by Ceva Animal Health (Barcelona, Spain). The authors are grateful to Alex Martino, Alessio Valenza, and Juan-Pedro Casas from Ceva Animal Health for their advice and support. Thanks are also extended to Ramón Costa and the technical team of the SGCE (Servei de Granges i Camps Experimentals) of the Universitat Autònoma de Barcelona (Bellaterra, Barcelona, Spain) for the care of the animals, and to Charles Simmons, native Englishspeaking former instructor of English (Cerdanyola, Barcelona, Spain) for the English language and style revision of the manuscript. The authors have not stated any conflicts of interest.

\section{REFERENCES}

Abecia, J. A., F. Forcada, J. A. Valares, I. Palacín, S. Martín, A. Martino, M. I. Gómez, and C. Palacios. 2005. Does melatonin treatment during lactation influence milk production in Lacaune and Assaf ewes? Span. J. Agric. Res. 3:396-401. https://doi.org/ 10.5424/sjar/2005034-166.

Adam, C. L., and J. G. Mercer. 2004. Appetite regulation and seasonality: implications for obesity. Proc. Nutr. Soc. 63:413-419. https: //doi.org/10.1079/PNS2004367.
Ait-Saidi, A., G. Caja, A. A. K. Salama, and S. Carné. 2014. Implementing electronic identification for performance recording in sheep: I. Manual versus semiautomatic and automatic recording systems in dairy and meat farms. J. Dairy Sci. 97:7505-7514. https://doi.org/10.3168/jds.2014-8090.

AOAC. 1990. Official Methods of Analysis of the Association of Official Analytical Chemists. 15th ed. Association of Official Analytical Chemists.

Auchtung, T. L., A. G. Rius, P. E. Kendall, T. B. McFadden, and G. E. Dahl. 2005. Effects of photoperiod during the dry period on prolactin, prolactin receptor, and milk production of dairy cows. J. Dairy Sci. 88:121-127. https://doi.org/10.3168/jds.S0022 $-0302(05) 72669-2$.

Auldist, M. J., S. A. Turner, C. D. McMahon, and C. G. Prosser. 2007. Effects of melatonin on the yield and composition of milk from grazing dairy cows in New Zealand. J. Dairy Res. 74:52-57. https: //doi.org/10.1017/S0022029906002160.

Avilés, R., J. A. Delgadillo, J. A. Flores, G. Duarte, J. Vielma, M. J. Flores, K. Petrovski, L. A. Zarazaga, and H. Hernández. 2019. Melatonin administration during the dry period stimulates subsequent milk yield and weight gain of offspring in subtropical does kidding in summer. J. Dairy Sci. 102:11536-11543. https://doi .org/10.3168/jds.2019-16836.

Bittman, E. L., F. J. Karsch, and J. W. Hopkins. 1983. Role of pineal gland in ovine photoperiodism: regulation of seasonal breeding and negative feedback effects of estradiol upon luteinizing hormone secretion. Endocrinology 113:329-336. https://doi.org/10.1210/ endo-113-1-329.

Bocquier, F., S. Ligios, G. Molle, and S. Casu. 1997. Effet de la photopériode sur la production, la composition du lait et sur les consommations volontaires chez la brebis laitière. Ann. Zootech. 46:427438. https://doi.org/10.1051/animres:19970505.

Borjigin, J., X. Li, and S. H. Snyder. 1999. The pineal gland and melatonin: Molecular and pharmacologic regulation. Annu. Rev. Pharmacol. Toxicol. 39:53-65. https://doi.org/10.1146/annurev .pharmtox.39.1.53.

Chemineau, P., I. Beltrán de Heredia, A. Daveau, and L. Bodin. 1996. High repeatability of the amplitude and duration of the nycthemeral rhythm of the plasma melatonin concentrations in the Ile-deFrance ewes. J. Pineal Res. 21:1-6. https://doi.org/10.1111/j.1600 -079X.1996.tb00264.x.

Cipolla-Neto, J., F. G. Amaral, S. C. Afeche, D. X. Tan, and R. J. Reiter. 2014. Melatonin, energy metabolism, and obesity: A review. J. Pineal Res. 56:371-381. https://doi.org/10.1111/jpi.12137.

Dahl, G. E., B. A. Buchanan, and H. A. Tucker. 2000. Photoperiodic effects on dairy cattle: A review. J. Dairy Sci. 83:885-893. https:/ /doi.org/10.3168/jds.S0022-0302(00)74952-6.

Elhadi, A., A. A. K. Salama, X. Such, E. Albanell, P. G. Toral, G. Hervás, P. Frutos, and G. Caja. 2019. Effects of shearing 2 breeds of dairy ewes during lactation under mild winter conditions. J. Dairy Sci. 102:1712-1724. https://doi.org/10.3168/jds.2018-15380.

Flores, C., G. Caja, R. Casals, E. Albanell, and X. Such. 2008. Performance of dairy ewes fed diets with a fibrolytic enzyme product included in the concentrate during the suckling period. Animal 2:962-968. https://doi.org/10.1017/S1751731108001961.

Gómez-Brunet, A., J. Santiago-Moreno, A. del Campo, B. Malpaux, P. Chemineau, D. J. Tortonese, A. Gonzalez-Bulnes, and A. LópezSebastián. 2008. Endogenous circannual cycles of ovarian activity and changes in prolactin and melatonin secretion in wild and domestic female sheep maintained under a long-day photoperiod. Biol. Reprod. 78:552-562. https://doi.org/10.1095/biolreprod.107 .064394 .

Haresign, W., A. R. Peters, and L. D. Staples. 1990. The effect of melatonin implants on breeding activity and litter size in commercial sheep flocks in the UK. Anim. Sci. 50:111-121. https://doi .org/10.1017/S0003356100004517.

Hooley, R. D., J. K. Findlay, and R. G. Stephenson. 1979. Effect of heat stress on plasma concentrations of prolactin and luteinizing hormone in ewes. Aust. J. Biol. Sci. 32:231-235. https://doi.org/ 10.1071/BI9790231. 
INRA. 2010. Institut de la Recherche Agronomique. Alimentation des Bovins, Ovins et Caprins. Éditions Quæ.

Kvetnoy, I. M. 1999. Extrapineal melatonin: Location and role within diffuse neuroendocrine system. Histochem. J. 31:1-12. https://doi .org/10.1023/A:1003431122334.

Lacasse, P., C. M. Vinet, and D. Petitclerc. 2014. Effect of prepartum photoperiod and melatonin feeding on milk production and prolactin concentration in dairy heifers and cows. J. Dairy Sci. 97:3589-3598. https://doi.org/10.3168/jds.2013-7615.

Lincoln, G. A., and I. J. Clarke. 1994. Photoperiodically-induced cycles in the secretion of prolactin in hypothalamo-pituitary disconnected rams: Evidence for translation of the melatonin signal in the pituitary gland. J. Neuroendocrinol. 6:251-260. https://doi .org/10.1111/j.1365-2826.1994.tb00580.x.

Mabjeesh, S. J., O. Gal-Garber, and A. Shamay. 2007. Effect of photoperiod in the third trimester of gestation on milk production and circulating hormones in dairy goats. J. Dairy Sci. 90:699-705. https://doi.org/10.3168/jds.S0022-0302(07)71553-9.

Mabjeesh, S. J., C. Sabastian, O. Gal-Garber, and A. Shamay. 2013. Effect of photoperiod and heat stress in the third trimester of gestation on milk production and circulating hormones in dairy goats. J. Dairy Sci. 96:189-197. https://doi.org/10.3168/jds.2012-5624.

Malpaux, B., C. Viguié, D. C. Skinner, J. C. Thiéry, and P. Chemineau. 1997. Control of the circannual rhythm of reproduction by melatonin in the ewe. Brain Res. Bull. 44:431-438. https://doi.org/10 .1016/S0361-9230(97)00223-2.

MAPA. 2007. Ministerio de Agricultura, Pesca y Alimentación. Guías de prácticas correctas de higiene Ovino de leche. Accessed Jun. 7, 2018. http://www.mapama.gob.es/es/ganaderia/publicaciones/ CCAE_tcm30-105306.pdf.

Misztal, T., E. Molik, M. Nowakowski, and E. Marciniak. 2018. Milk yield, lactation parameters and prolactin secretion characteristics in sheep treated with melatonin implants during pregnancy and lactation in long-day conditions. Livest. Sci. 218:58-64. https:// doi.org/10.1016/j.livsci.2018.10.018.

Misztal, T., K. Romanowicz, and B. Barcikowski. 1997. Natural and melatonin - stimulated changes in the circadian rhythm of prolactin secretion in the ewe during seasonal anestrus. Neuroendocrinology 66:360-367. https://doi.org/10.1159/000127259.

Misztal, T., K. Romanowicz, and B. Barcikowski. 2001. Short-term modulation of prolactin secretion by melatonin in anestrous ewes following dopamine - and opiate receptor blockade. Exp. Clin. Endocrinol. Diabetes 109:174-180. https://doi.org/10.1055/s-2001 -14842 .

Molik, E., G. Bonczar, T. Misztal, A. Zebrowska, and D. Zieba. 2012. The effect of the photoperiod and exogenous melatonin on the protein content in sheep milk. Pages 325-340 in Milk Protein. W. Hurley, ed. InTech. https://doi.org/10.5772/46101.

Molik, E., T. Misztal, K. Romanowicz, and E. Wierzchos. 2007. Dependence of the lactation duration and efficiency on the season of lambing in relation to the prolactin and melatonin secretion in ewes. Livest. Sci. 107:220-226. https://doi.org/10.1016/j.livsci 2006.09.013.

Molik, E., T. Misztal, K. Romanowicz, and D. Zieba. 2013. Short-day and melatonin effects on milking parameters, prolactin profiles and growth-hormone secretion in lactating sheep. Small Rumin. Res. 109:182-187. https://doi.org/10.1016/j.smallrumres.2012.10.006.

Molik, E., T. Misztal, K. Romanowicz, and D. A. Zieba. 2010. The effects of melatonin on prolactin and growth hormone secretion in ewes under different photoperiods, during the early post partum period. Small Rumin. Res. 94:137-141. https://doi.org/10.1016/j .smallrumres.2010.07.014.
Molina, E., A. Ferret, G. Caja, S. Calsamiglia, X. Such, and J. Gasa. 2001. Comparison of voluntary food intake, apparent digestibility, digesta kinetics and digestive tract content in Manchega and Lacaune dairy sheep in late pregnancy and early and mid-lactation. Anim. Sci. 72:209-221. https://doi.org/10.1017/ S1357729800055703.

Mura, M. C., S. Luridiana, G. M. Vacca, P. P. Bini, and V. Carcangiu. 2010. Effect of genotype at the MTNR1A locus and melatonin treatment on first conception in Sarda ewe lambs. Theriogenology 74:1579-1586. https://doi.org/10.1016/j.theriogenology.2010 .06 .028 .

Notter, D. R., and P. Chemineau. 2001. Nocturnal melatonin and prolactin plasma concentrations in sheep selected for fertility in autumn lambing. J. Anim. Sci. 79:2895-2901. https://doi.org/10 $.2527 / 2001.79112895 x$

Notter, D. R., N. E. Cockett, and T. S. Hadfield. 2003. Evaluation of melatonin receptor $1 \mathrm{a}$ as a candidate gene influencing reproduction in an autumn-lambing sheep flock. J. Anim. Sci. 81:912-917. https://doi.org/10.2527/2003.814912x.

O'Callaghan, D., F. J. Karsch, M. P. Boland, and J. F. Roche. 1991. What photoperiodic signal is provided by a continuous-release melatonin implant? Biol. Reprod. 45:927-933. https://doi.org/10 $.1095 /$ biolreprod45.6.927.

Reiter, R. J. 1980. The pineal and its hormones in the control of reproduction in mammals. Endocr. Rev. 1:109-131. https://doi.org/ 10.1210/edrv-1-2-109.

Reiter, R. J. 1991. Melatonin: That ubiquitously acting pineal hormone. Physiology (Bethesda) 6:223-227. https://doi.org/10.1152/ physiologyonline.1991.6.5.223

Reiter, R. J., D. X. Tan, and A. Korkmaz. 2009. The circadian melatonin rhythm and its modulation: Possible impact on hypertension. J. Hypertens. Suppl. 27:S17-S20. https://doi.org/10.1097/01.hjh $.0000358832 .41181 . \mathrm{bf}$.

Russel, A. J., J. M. Doney, and R. G. Gunn. 1969. Subjective assessment of body fat in live sheep. J. Agric. Sci. 72:451-454. https:// doi.org/10.1017/S0021859600024874.

Song, Y. M., and M. D. Chen. 2009. Effects of melatonin administration on plasma leptin concentration and adipose tissue leptin secretion in mice. Acta Biol. Hung. 60:399-407. https://doi.org/10 .1556/ABiol.60.2009.4.6.

Van Soest, P. J., J. B. Robertson, and B. A. Lewis. 1991. Methods for animal dietary fiber, neutral detergent fiber, and non-starch polysaccharides in relation to nutrition. J. Dairy Sci. 74:3583-3597. https://doi.org/10.3168/jds.S0022-0302(91)78551-2.

Williams, A. H., S. R. McPhee, J. L. Reeve, and L. D. Staples. 1992 Optimum use of subcutaneous melatonin implants to enhance the reproductive performance of seasonal and non-seasonal sheep joined in spring and early summer. Anim. Reprod. Sci. 30:225-258. https://doi.org/10.1016/0378-4320(92)90012-3.

Zarazaga, L. A., B. Malpaux, L. Bodin, and P. Chemineau. 1998. The large variability in melatonin blood levels in ewes is under strong genetic influence. Am. J. Physiol. 274:E607-E610. https://doi.org/ 10.1152/ajpendo.1998.274.4.E607.

\section{ORCIDS}

A. Elhadi $\odot$ https://orcid.org/0000-0003-4354-7105

A. A. K. Salama ๑ https://orcid.org/0000-0003-2065-9702

X. Such @ 1 https://orcid.org/0000-0002-9712-4477

G. Caja @ https://orcid.org/0000-0001-8606-3587 